Al-Bidayah : jurnal pendidikan dasar Islam

Volume 13, Number 1, June 2021

ISSN: 2549-3388 (online)

Available online at https://jurnal.albidayah.id

Submitted: February 27, 2021, Accepted: June 28, 2021

\title{
THE ROLE OF INFAQ IN BASIC EDUCATION DEVELOPMENT IN THE ACEH COMMUNITY
}

\author{
Maemonah $^{1}$, Fitri Yuliawati ${ }^{2}$, Azizah Uswatun Hasanah ${ }^{3}$ \\ UIN Sunan Kalijaga Yogyakarta, Indonesia ${ }^{1,2}$, UIN Ar-Raniry Banda Aceh, Indonesia ${ }^{3}$ \\ E-mail: maimunah@uin-suka.ac.id ${ }^{1}$, fitri.yuliawati@uin-suka.ac.id ${ }^{2}$, \\ azizah.hasanah@ar-raniry.ac.id ${ }^{3}$
}

DOI: 10.14421/al-bidayah.v13i1.633

\begin{abstract}
After the tsunami disaster and Aceh political reconciliation, awareness of education's importance began spreading to the villages. The awareness creation process is preferable because the prominent supporters of this effort are the people only. At the same time, the Indonesian government's role is also active in gaining a positive image in the province. Therefore, this paper investigated the level of community awareness in setting aside a portion of the members' income to build elementary schools, pay teacher salaries, and meet other educational needs. The result showed that the community movements were not positively correlated with management and awareness-raising and the general donation movement in Aceh. Besides, community education empowerment has been fast considering various possible future challenges to be encountered. Nevertheless, the targeted awareness has not been accompanied by public attention towards building higher-quality educational facilities and infrastructure.
\end{abstract}

\section{Keywords: Aceh; basic education; infaq}

\section{INTRODUCTION}

In Aceh, madrasah (school) is inseparable from the figure and role of the ulama. ${ }^{1}$ Hence, the classic study of Acehnese ulama (Islamic scholars) written by Alfian shows the ulama has established religious education centers known as Dayah or Pesantren. Even though they do not use the term madrasah, Dayah has taught the students spiritual sciences. For instance, Dayah was founded by ulama, an educational institution built by Teungku Abdul Wahab in 1926 at the Seulimeum District. In the following years, the term madrasah was only used, such as Madrasah al-Muslimin Peusangan, founded by TeungkuAbiurrahman in 1930. Besides the ulama, other charismatic figures, namely Uleebalang, meaning community leaders that participated in taking Aceh from the Netherlands, also played an essential role in educational development. ${ }^{2}$ Ulama and other

${ }^{1}$ Definitely, the role of the ulama is not only from the education point of view, another essential one concerning the Acehnese ulama is their struggle in fighting against colonialism. Portuguese and Netherlands were in Aceh since the $16^{\text {th }}$ century. Amirul Hadi, "Aceh and the Portuguese : a study of the struggle of Islam in southeast Asia, 1500-1579” (McGill University), Xii, accessed February 5, 2021, https://escholarship.mcgill.ca/concern/theses/9306t0349.

2 Alfian, "The Ulama In Acehnese Society: A Preliminary Observation," Southeast Asian Journal of Social Science 3, no. 1 (1975): 27-41, https://www.jstor.org/stable/24489966. 
intellectuals encountered the same challenges, i.e., how religious education faces the challenges of an increasingly complex era, including the modernization and secularization process of madrasah.

Long after the tsunami, the challenge of religious education was not only the openness of education managers such as ulama, uleebalang, or the state but also financial capacity. Based on Elizabeth Frankenberg et al., $2016^{3}$, community relocation is social relocation with software and hardware in it to create a quality education in a post-disaster community that required substantial financial resources due to performing the learning process on a fragile social construction footing. Following the disaster's occurrence, a peaceful agreement was also reached between GAM and Indonesia, where one of the primary points is Aceh's right to autonomy in managing regional finances and law. In the context of regional financial management, according to regulation the act. no. 11 of 2006, Qanun no 10 of 2007, and Aceh governor regulation no. 60 of 2008, the terminology of zakat was transferred to tax or from tax to zakat. Hence, recently, the qanun has not been effective because there are no technical regulations on how zakat became a tax. ${ }^{4}$ This finding means that in implementing the Islamic law qanun, there are many obstacles and homework encountered, including regulations on infaq. There are still lots of homework to execute to collect public funds for social purposes.

One factor that makes madrasah lag behind other educational institutions at the primary, secondary, and upper levels is the lack of financial management and empowerment, and funding sources. Academic scholars perceive madrasah's management system causes the above conditions in all its traditional aspects. This view means to start catching up with underdevelopment, and the institution needs to be managed in a modern way. However, the current management is not merely a curriculum aspect mentioned by Lukens Bull ${ }^{5}$, but also involves human resources, society, institutions, students, and finance.

\footnotetext{
${ }^{3}$ Elizabeth Frankenberg et al., "Education, Vulnerability, and Resilience after a Natural Disaster," Ecology and Society : A Journal of Integrative Science for Resilience and Sustainability 18, no. 2 (2013): 16, https://doi.org/10.5751/ES-05377-180216.

${ }^{4}$ Sri Nurhayati and Dodik Siswantoro, "Factors on Zakat (Tithe) Preference as a Tax Deduction in Aceh, Indonesia," International Journal of Nusantara Islam 3, no. 1 (August 13, 2015): 1-20, https://doi.org/10.15575/ijni.v3i1.133.

${ }^{5}$ Ronald A. Lukens-Bull, "Two Sides of the Same Coin: Modernity and Tradition in Islamic Education in Indonesia," Anthropology \& Education Quarterly 32, no. 3 (2001): 350-72, https://doi.org/10.1525/aeq.2001.32.3.350.
} 
At the same time, madrasah's traditional identity is not ultimately interpreted negatively. The aspects of solidarity, cooperation, and social exclusion often turn positive in a traditional society where the madrasah has its roots. Therefore, such positive values need not be eliminated immediately but instead reconstructed to become a modern entity while having the spirit and positive values that exist in traditional elements. Furthermore, people's attraction to madrasah is not always due to the source of the excellence of the curriculum, teaching staff, or other available educational facilities. The term madrasah, for some people, is the right choice, even though the situation is straightforward. Its enthusiasts decide not always because the institution is considered qualified, but possibly due to being called a madrasah, not a school, or something else. ${ }^{6}$

Initially, there were schools (Madrasahs) on the initiative of several community leaders, which voluntarily contributed part of their fortune in money, land, and labor. Donation in Islam means Shadaqah or infaq, simply defined as the process of voluntarily giving out money or goods that are not used once. Infaq is generally manifested in the form of cash, hence containing sustainable values both during giving (investment) and in terms of management. The charitable also act runs in a dialectically continuous manner and does not travel in one direction. So, the giver can give to the recipient person/institution. Then, the giver gets back benefits and use-value. The tradition of providing infaq is more natural and classic than zakat since it arises with the full awareness of those giving and is motivated by personal attention. The historical and theoretical explorations showing this have been conducted by Idris Hamid Muhammad Ali, especially in the al-Qur'an's context.

In contrast to zakat with clear guidelines and rules which has become a written law, as stated by QurratulUyun in Zakat, Infaq, Shadaqah, and Waqf as the Configuration of Islamic Philanthropy, ${ }^{7}$ infaq is more of a convention of how one is encouraged to donate. However, in some countries, infaq serves as a measure of social awareness developing in society. There is even a lot of evidence to show the funding for unusual activities is also administered using the infaq concept. Based on the study conducted by

${ }^{6}$ Imam Suprayogo, Quo Vadis Madrasah: Gagasan, Aksi Dan Solusi Pembengunan Madrasah (Yogyakarta: Hikayat, 2007), 67-69.

${ }^{7}$ Nurhayati and Siswantoro, "Factors on Zakat (Tithe) Preference as a Tax Deduction in Aceh, Indonesia." 
ZacharryAbuza ${ }^{8}$, this fact stated that the fundraising process conducted by radical movements in Southeast Asia is more effective in using the terms infaq and shadaqah rather than zakat. In the same context, according to Hilman Latif, ${ }^{9}$ Infaq has become part of the source of Islamic philanthropy that can be developed in various fields, including health and education. In line with the Yogyakarta Coin a Chance (YCAC) community group, elements of philanthropy are traced from fundraising, funds management, and utilization of social funds, indicated by the presence of foster siblings and foster parents ${ }^{10}$. Azira Hanani ${ }^{11}$ also conducted a study in the education sector to manage infaq collection in private schools in Perak, Kelantan, and Kedah, indicating that a good school reputation increases income through large infaq. This finding is different from SDIT Hafidzul Ilmi, where the school was built from community infaq, regardless of its reputation. Sabirin ${ }^{12}$, Eko Gondo Saputro ${ }^{13}$, and Muhammad Haris Riyaldi, studies on other infaq have not focused much on education. ${ }^{14}$

The three scholars mentioned above studied Baitul Mal in Aceh to collect and distribute zakat, infaq, and alms among Muslims. They agreed the institution affected the Acehnese economy on which the distribution process has however not yet had a productive impact. From existing sources, there has been no study on infaq that has a specific effect on Islamic education, especially for the Acehnese. Therefore, the investigation entitled The Role of Infaq in the Development of Basic Education In Aceh Community has urgency, where this city is the center of the civilization and development

${ }^{8}$ Zachary Abuza, "Funding Terrorism in Southeast Asia: The Financial Network of Al Qaeda and Jemaah Islamiya," Contemporary Southeast Asia: A Journal of International and Strategic Affairs 25, no. 2 (2003): 169-99, https://muse.jhu.edu/article/387728.

${ }^{9}$ Hilman Latief, "Health Provision for the Poor Islamic Aid and the Rise of Charitable Clinics in Indonesia," South East Asia Research 18, no. 3 (September 1, 2010): 503-53, https://doi.org/10.5367/sear.2010.0004.

10 Rosa Diyana, "Filantropi Pendidikan Studi Kasus Komunitas Yogyakarta Coin A Chance" (Skripsi, UIN Sunan Kalijaga Yogyakarta, 2016), https://digilib.uin-suka.ac.id/id/eprint/20989/.

11 Azira Hanani Ab Rahman and Sofri Yahya, "The Relationship between Reputation and Infaq Collection among Islamic Private Schools and the Role of Governance Practice as Moderator" (Sintok International Conference on Social Science and Management (SICONSEM 2017), Adya Hotel, Langkawi Island, Kedah, Malaysia, 2017), 75-76, http://repo.uum.edu.my/24538/.

12 Sabirin et al., "The Assistance Model of the Baitul Mal in Promoting The Community of Home Industry," International Journal of Criminology and Sociology 9 (September 7, 2020): 357-64, https://doi.org/10.6000/1929-4409.2020.09.34.

${ }^{13}$ Eko Gondo Saputro and Sahabudin Sidiq, "The Role of Zakat, Infaq and Shadaqah (ZIS) in Reducing Poverty in Aceh Province," International Journal of Islamic Economics and Finance (IJIEF) 3, no. 0 (September 2, 2020): 63-94, https://doi.org/10.18196/ijief.3234.

${ }^{14}$ Muhammad Haris Riyaldi and Farah Maulida Sari, "The Analysis of Welfare Determinant Factors of Recipients Zakat, Infaq and Sedekah (ZIS) Productive in Baitul Mal Aceh," in International Conference of Zakat, 2018. 
of Islam in the province that applies sharia. The implementation of education follows the rules set by the local government as the implementer of state laws in specific fields and Islamic law in other areas. Infaq as a source of fundraising in sharia needs to be a unique attraction for a society with a constitution that uses Islamic law. However, the facts on the ground are not always the case. Awareness of donating for education is driven more by knowing about the importance of education than by the extent of enforcing Islamic law. Not all madrasahs or elementary schools perform infaq, which is Islamic teaching, besides zakat. Therefore, this study focuses on only a few madrasahs or SD (Primary Schools) in Banda Aceh with infaq programs. The madrasah or SD in question is SD IT HafidzulIlmi, Islamic, to ensure not being much different from a madrasah. The difference is when the madrasah is under the Ministry of Religion while SD IT is under the Ministry of Primary and Secondary Education.

Infaq is one of the sources of funding for SD IT Khafidulllmi. Furthermore, several things need attention in funding in schools, which is, at a minimum, four structural weaknesses in the current education funding system. When not resolved, these problems affect the quality of education in general. The first weakness is the domination of funding from the government and parents, unfair and inadequate allocation of the available education budget, and inefficiency in the administration of educational institutions. The government and parents dominate the current sources of education funding. The participation of the community and the industrial world is still minimal in supporting the needs for operational education expenditures, which range from only $2-8 \%$. This phenomenon is because the community's contribution and the business world are more manifested in donated land grants, school construction, and the provision of educational equipment.

Other facts also show an imbalance in the proportion of funding from the government to all schools. The private schools, which generally accommodate more students from underprivileged families, often receive fewer subsidies. Such a background also encourages various parties to collect and manage funds independently, for instance, by developing infaq, sadaqah, and zakat. The three forms of social contribution are one of the strengths and resilience of society in building independence to promote education's advancement for better future generations. 


\section{RESEARCH METHODS}

This research was a type of field study, known to be in-depth, intensive, and detailed in understanding a specific object in society that requires in-depth and comprehensive understanding and analysis. ${ }^{15}$ Furthermore, it was oriented towards understanding the donation system in an Islamic educational institution in Aceh, SD IT Hafizul' Ilmi.

Meanwhile, a qualitative approach was used to examine existing, which then produced descriptive data. The main aim was to describe an existing exemplary process, currently available, which tended to occur when conducting this study and analysis of the objective approach, constraints, and vision of the incident in-depth. ${ }^{16}$ In determining the location to be used, the selection samples or representations of the hundreds of schools (madrasah) in Aceh used the concept of sampling.

Data collection used direct observations and interviews to determine school funding sources, infrastructure, public awareness of education, and the learning process. Meanwhile, we also observed the documentation of infaq, curriculum, and distribution of the funds generated. The interview was inseparable from the role of the informants that included the village head and secretary, as well as the principal, teachers, the school treasurer, student guardians, and community leaders.

\section{RESULT AND DISCUSSION}

\section{Awareness of the Importance of Education}

The establishment of educational institutions such as kindergartens and elementary schools in Aceh after the tsunami incidence ${ }^{17}$ and reconciliation between GAM and Indonesia is an exciting study. Before this period, infrastructure development, primarily educational institutions for children coupled with a comfortable and safe learning process, was described as a tense affair to add, supposing the process had entered

\footnotetext{
${ }^{15}$ Suharsimi Arikunto, Prosedur Penelitian: Suatu Pendekatan Praktek (Jakarta: Rineka Cipta, 1998), 11.

${ }^{16}$ Hussain Umar, Metode Penelitian Untuk Skripsi, Tesis, Dan Disertasi (Jakarta: Rajawali Press, 2011), 20-23.

${ }^{17}$ Syamsidik et al., "Fifteen Years of the 2004 Indian Ocean Tsunami in Aceh-Indonesia: Mitigation, Preparedness and Challenges for a Long-Term Disaster Recovery Process," International Journal of Disaster Risk Reduction 54 (February 15, 2021): 102052, https://doi.org/10.1016/j.ijdrr.2021.102052.
} 
GAM-controlled villages. Difficulty in access, security, transportation, and community cohesion \& solidarity are very complex issues.

Therefore, it was concluded that establishing schools/madrasah or generally infrastructure and superstructure development before reconciliation is complicated for both the government and the community. The pre-reconciliation process of children's education only relied on traditional educational institutions in Aceh, often referred to as Meunasah and Dayah. However, there is a need to admit that even traditional educational institutions remained part of the effects and elements of the social and political conflicts at that time.

Besides, Meunasah, often referred to as Meulasah or Beulasah, is a permanent open building owned by the public as a centre for community activities, information, and education. The word is believed to have emanated from the Arabic language madrasah or a place of learning. However, the Acehnese seemed to have used Meunasah as a place to explain various things. If this is true, it can be concluded that the institutions and social communication processes of the Acehnese can be concluded as the communities that initially formed the madrasah, which formed society. Why? Because there is a symbol of community cohesion and interaction in its traditional educational institution called Meunasah. Meunasah is not separated from the Acehnese because of its central role as they both form an integrated unit. More explicitly, the existence or extinction of Meunasah leads to Acehnese's existence or extinction, and vice versa. This phenomenon is because the Meunasah is the Acehnese's symbol, identity, and culture. ${ }^{18}$

Meunasah is the embryo of the Acehnese's existence as a social identity that has personal culture and rules. Therefore, it cannot be claimed as an educational institution in the sense of tarbiyyat al-awlad but as tarbiyat al-rijal and more as a centre for information and community development at the village level. The process of communication and social interaction was facilitated simultaneously with the establishment of an educational institution. This education institution was later known as Meunasah. Therefore, in the Meunasah, there is a bath and a place for ablution (kullah), while there are prayer activities, Qur'an learning, and studying of Islam usually followed by boys that have

${ }^{18}$ Badruzzaman Ismail, Mesjid Dan Adat Meunasah Sebagai Sumber Energi Budaya Aceh (Banda Aceh: Gua Hira, 2002), 1-2. 
reached puberty. They stay and sleep in this building as part of the mental, spiritual, and social tender process.

Along with the development of time and society and the spreading of Islam, which was increasingly widespread and comprehensive, education and religious centres were explicitly created, but differing from the Meunasah. The education center is called Dayah or Pesantren, but the mosque is used for religious activities. According to James T. Siegel's view, Dayah has existed since the Sultanate while contributing to the overall life of the community and performing a social function, especially in the religious discipline. The Acehnese, especially the young ones, mostly trade and migrate to gain knowledge. Therefore, according to Mashuri, Dayah or Islamic boarding schools in Aceh have shown their active participation together with elements of society, including the government, in the success of development programs, especially in terms of religious life and the nation's children intelligence. The struggle for historical literature and social dynamics dialectically cause Dayah to have awareness and concern to participate in overseeing the nation's journey following the ideals of religion and society universally. ${ }^{19}$

When viewed from the historical aspect, as explained by Mashuri and Marzuki, the scope of Dayah's meaning and concept in the pre-war Aceh period, in 1873, includes education in Meunasah-Meunasah, rangkang, Dayah Teungku Chik to al-jami'ah education, such as the mosque of Raya Baiturrahman in Banda. The existence of such institutions is observable from various historical heritage sites, including the Teungku Awe Geutah Dayah in Peusangan, the Teungku Chikin Tiro (Syekh Saman), the Teungku Chik Tanoh Abee Dayah in Seulimum, the TeungkuDayah in Lamnyong, the Lambhuek Dayah and the Dayah in Krueng Kalee. However, as the institution progressed, the power of existence entered its ups and downs. Dutch colonialism in Aceh contributed to the weakening of Dayah in society. This institution experienced strengthening again after independence, and there has been a modernization process until now. Hence, Dayah is the basis of religious education which also organizes general instruction such as junior high school (or called SMP in Indonesia) or senior high school (or called SMA in

${ }_{19}$ Mashuri Mashuri, "Dinamika Sistem Pendidikan Islam Di Dayah,” Jurnal Ilmiah Didaktika: Media Ilmiah Pendidikan Dan Pengajaran 13, no. 2 (February 1, 2013): 259-70, https://doi.org/10.22373/jid.v13i2.477. 
Indonesia) and vocational high school (or called SMK in Indonesia), while some already have tertiary institutions. ${ }^{20}$

At this historical point, the modernization of Islamic education in Aceh began to abandon the Meunasah, Dayah, and even the mosque. Meaning, in the current context, especially in the post-reconciliation era, educational institutions are based on religion but with some differences, and they do not even have the idea or concept of Meunasah or Dayah in it. Generally, such transformation is positioned as part of changing traditional Islamic education into a modern form.

The efforts to build Islamic education institutions in Acehnese society are no exception in similarity with how this activity has been performed by the people of Gampong BlangKrueng regardless of whether the existing settlement is old or newly developed after the tsunami incidence. They continue to make efforts to educate the nation's children in various ways following the era's spirit. There is a great spirit rising among the Acehnese today, especially after the tsunami, to establish (mostly elementary) educational institutions. "The struggle we faced in building the school was full of tears of blood." That was what the village head, TeungkuCik, said during the first visitation. According to scholars, the tears of blood that were shed after the tsunami need to be understood as a blessing for the people of Aceh to facilitate the occurrence of reconciliation.

Furthermore, the relationship between these educational institutions and the tsunami incident was explained. "If you sit in the meeting room class at SD IT HafizulIImi, you will see a map that was made in 2006, and that is the map of the village's Master Plan." Meaning that after the tsunami, the village had aspired to own one school. The dream existed because the town had the commitment and desire to develop its town by building human resources. "How do we want to create human resources if there is no educational institution in the village? Hence, this is a way to change character".

The explanation of the Gampong head shows how the tsunami brought blessings. The people united built a new community with a new system and pattern of social interaction. Moreover, supposing the village was once the basis of GAM (Free Aceh Movement), how they were developed the education can be imagined. Just finding a sense

${ }^{20}$ See more Marzuki Marzuki, "Sejarah Dan Perubahan Pesantren Di Aceh,” Millah: Jurnal Studi Agama 11, no. 1 (2011): 225-26, https://doi.org/10.20885/millah.vol11.iss1.art11. 
of security is problematic because it is on the front lines of the conflict area between GAM and the TNI (Indonesian Army). The head of BlangKrueng village also said, "It should be noted that this village was once the base of GAM, and a school is a place for GAM training, so there is also assistance provided from GAM who has repented." However, notably, this place is the base of GAM, and the desire of the local people to attend school is lacking. Starting from the conflict period until after the tsunami, the residents' willingness towards schooling was deficient, plus some families were less fortunate but wanted to be educated, but the capacity of the surrounding schools was minimal.

Two historical facts need to be underlined here; first, social conditions are unconducive or unsafe, causing society to prioritize basic things to send their children to school. Second, the village infrastructure damaged or neglected due to social conflicts makes it difficult for the community to obtain education for various families and children. After the tsunami and reconciliation, public awareness to send children to school began to grow. The descriptions conveyed by Teungku Cik, for instance, were quite interesting. "There are parents of crying children who come to the village head because their children do not go to school (limited capacity). This is the background of the school we build ". (The sensitivity of the village leadership must be appreciated, and knowing the reason for conceiving such thoughts is necessary)

The sensitivity of village leaders to educate the nation's children is the driving force for their devotion by designing schools to be known even until the preparation of the world plan two years after the tsunami. According to the village leaders,

"hence, this school has indeed been designed with the world plan in 2006 to become the center of education. Then, in 2008, we tried to submit a proposal to the agency, but there was no answer. Then, we put it in the Village Development Plan (RPG) so that the hope is that there are parties who want to build it but have not succeeded. Then, I said to the father, who is now the head of the foundation, that if we want to build a school, there must be an actor driving it. If you are ready, I am ready."

The facts above show that the background and efforts to establish educational institutions are not only motivated by the willingness of the village head or leaders, but cooperation with other community leaders or the general public is also needed. The description above is very clear about how the village leaders invited other figures to build together. The participation of different elements in society is one of the success factors of 
GampongBlangKrueng in building primary educational institutions for the village community.

Donations of human resources, funds collected from the community through recitation forums, and others were further explained.

"Ordinary people raise 20,000 funds, while some give 10,000, some even give 500,000 , no matter how easy it is. Even something makes us touched, and there is one citizen who donated 7 million for us. Alhamdulillah, we collected 40 million rupiahs in funds. This donation is the initial capital we then use to buy benches, and renovation of the building assistance from Malaysia, which incidentally is not yet functional, is divided into two rooms. So that in the first year, Alhamdulillah received two locals (class)". "In 2015, we immediately recruited students and teachers. I was the one who interviewed the teacher, and my question: Why are you interested in applying here? Furthermore, willing not to serve without pay? This experience is an important note for us, and Alhamdulillah we pay them today, even though the payment is still below the UMP (Provincial Minimum Wage)".

The above statement indicates that the element of generosity or philanthropy is very much the basis and the driving factor for the growth and development and the existence of Islamic education, especially at the beginning of its establishment. In Islam, building educational institutions with a very calculated business model that uses profit parameters seems complicated. The growth and development of Islamic education always depart from a collective sense of generosity. This foundation or basis for community philanthropy is a sign and also an impetus for other charitable social business activities that one of the major assets which Muslim communities have in building their society and religion is generosity, or often referred to as cooperation in different languages.

\section{Learning and Financing}

Ideal and maximum learning requires much money; therefore, an even higher budget is needed. However, amid limited funds owned by the school, teachers among HafidulImi seem satisfied with a modest salary even though the workload to be executed is much heavier than the monthly salary. The principal and teachers understand it as part of the principle of rizqi accepted by every human being. According to the village, even with a small amount of money, there are still many educational activities." Even though the teacher's salary is mediocre, the teachers here are sincere, and the term is a sweet fruit that we can pick. That is why we always say that the teachers here do not expect a salary, because that is what school can give, but Alhamdulillah, if we are sincere, there will be sustenance for us. Because nourishment can come from anywhere, working sincerely is 
the first thing to be conveyed to the teachers here. By working sincerely, we will also feel less tired and enjoy school time. Hence, here, we always convey, both to teachers and PP1 students who come to do internships here, that sincerity is the main thing". As further stated, in this school, the funding (money) entry is not too expensive. When someone says: "This is IT, private school and is very cheap," "we still do not take the costly monthly fee. The consideration is that we also have to think again about the background conditions of the residents here are not the same. Some work as construction workers, most of whom come from the lower middle class. If the middle class and above, I think they are already able to pay higher fees."

Apart from SPP (school fee), the community also thinks about the sustainability of this education, especially in teacher salaries and school needs, which are not small. The view of the village head emphasizes,

"When education has been conducted, our thoughts immediately turn on. That is, we think about the teachers' needs. Thus, several solutions emerged; First, we have shared with government officials several times so that the village head's salary budget agrees to allocate donations for teachers before they have a budget. Second, we have also budgeted for the APBG (Gampong Revenue Budget), which comes from village businesses such as rental house businesses. There are also events in the village which generate income and then allocated, partly, to teachers. In essence, there are efforts made continuously by the village to provide small honoraria to teachers".

Furthermore, "as time goes by, when the students are busy, we make rules together with the committee, and the parents and guardians also contribute. If I am not mistaken, it was 50 thousand people in that first year, and the solution for students who cannot afford it is cross-subsidies, which is by creating a foster parent program. Hence, today, there are several children under the foster parent movement. In addition, the teachers are also looking for scholarship solutions for underprivileged children. They were negotiating and lobbying the Baitul Mall and people who have the ability so that this program continues until now. We also from the village side invite officials to serve in charity, and this will continue until we get out of the operational permit, so that there is already a boss's fund and the $20 \%$ can be used for teacher salaries and Alhamdulillah the teachers can breathe because their payment is sufficient and of course, it is far from ideal".

According to Teungku Cik, the Gampong also strives continuously for teachers to become civil servants to ensure schools exist and residents also get permanent jobs. Hence this is the vision of building an IT school in this village. Alhamdulillah, the community 
is very supportive; even the members are willing to donate their land, like one person donating up to $1000 \mathrm{~m}^{2}$ of land. Meaning, in the context of education, there is an attitude of generosity through infaq from students and awareness of the community, government officials, and other parties to build schools or madrasah and develop them.

\section{Building a Tradition of Generosity and Togetherness for Education}

As explained above, education is developed simultaneously by building the generosity of all parties, from teachers, foundations, society, or government or state officials. It is important to underline because in terms of funding, according to the principal and village head, the school initially had no grants, but in 2016 there were only central government grants. The school socialization taught to the community was also free of charge because it was always conveyed in routine learning activities for fathers and mothers in Blangkrueng village and generally, this study was conducted at night. Besides learning from tengku-tengku (ustad or Islamic teachers), the importance of education was also conveyed. For further explanation, this is a religious school, functioning to make the children the next generation that loves the Qur'an, has morals meant to shape character from an early age, good habits that are always used in school, and the daily manners all as the initial foundation. When the children enter primary school (SD), they are ready and have a stepping stone. Whatever habituation is taught here, it becomes habituation for students, such as memorizing the hadiths that tend to be continuous. Also, feedback is provided when the children are enrolled in a religious school (or called TK IT in Indonesia).

According to the principal, the details of significant funding were never delivered. However, there was funding at the time of admission. Meanwhile, the details of the large, drafted budget were immediately held by the Gampong. This foundation is village-owned to ensure a backup is offered to the school in general. As stated, in comparison this current year, a wireless APE (Educational Game Tool) is needed to draft a Gampong budget. The Village Secretary was met immediately as a form of intervention in Gampong Blangkrueng for the procurement; then, they have those details. Further stated, "we are here as the management only, if it is for the procurement of necessities such as cabinets, they will prepare these needs, such as recently there was a repair on the floor, iron trellis, the Gampong directly went to the school to measure, or cast, so our needs were also 
conveyed. According to Astuti, some of the money for school needs comes from the ABG (Gampong Budget) fund, so we only provide a draft budget, but clearly, we make it. From us, if the money already exists, it is directly stored to the parties involved, such as recently for the procurement of uniforms, we immediately deposit it to that party."

In addition to relying on the Gampong budget, according to SDIT treasurer HafidzulIImi, there are also foster parents at SD IT Hafidzul Ilmi, which are both guardians that want to help reduce monthly tuition fees for the respective student or other matters. In the first year, the foster parents also bear the equipment of the book. In the previous year, it only lasted for one year. Hence, in the current, someone willing to stand in is being searched. When the child is constrained by one year of tuition fees, foster parents are searched again despite being limited because these people do not want the underprivileged to stop going to school. As an alternative, foster parents are searched, both from outsiders and among the student's guardians. According to the HafidzulIlmi SDIT Board, the amount of the SPP depends on the year of entry. In the first year, it is only Rp. 50,000 , and that is until they are in grade 6 , but in the $4^{\text {th }}$ year, the SPP is Rp. 150,000. Meanwhile, the salaries provided come from SPP funds and are assisted from ABG funds (Gampong Assistance Budget) and those for which there is already a Perbup (Regent Regulation). Hence, from the ABG funds, a small amount was allocated for schools because for the PAUD level, paying attention was necessary due to the low level of salary.

In addition to the strength of SPP, the jumatan infaq boxes are also a mainstay of the continuity of education. The current infaq box has been promoted. Every Friday, the children donate the allocated funds for qurban. Therefore, yearly, the qurban fund that is not sufficient is added with the money, while all the collected infaq cannot be used for others because it was intended for qurban. In the committee meeting, the possibility of a special infaq was proposed for parents in addition to the SPP infaq often used to fund school activities.

Apart from jumatan infaq, according to Astuti, there is also sadaqah from the gampong apparatus. Moreover, and some also set aside their salaries to be helped. They include apparatus from the village head (gampong), kecik (village secretary), tuhapeut, and others that collect a salary from the village (gampong), due to the main educational priorities. For education issues, this village tends to remain the number one, same as the 
case in SD IT development which is also the community's self-help. For the current year, the schooling children are in grade 4 . Two classes have been built again for the following year when they need to move up to grades 5 and 6 . Hence, this was commenced by executing the task little by little. Kindergarten and SD are already in the fourth year, the same as their launching in 2015, and Alhamdulillah for the first year, they are quite busy, even though they only exist in the village. Moreover, the number of students in the first year is 45 students. This is a very rare beginning, making the heads of offices that come directly to be also happy because such has never been experienced in the first school built with 45 children, but at most 5 or 6 people.

According to the Gampong head, calls for giving are always echoed to the public in religious forums. Furthermore, for the Acehnese, these messages were conveyed through lectures because they are fond of hearing such. As stated, "Hence, if we make a lecture, let alone have food (as a trick/system innovation), we can convey the message that we want to the citizens if there is no food. Thus, at the time of the launch, why did the communities donate? This was what the lectures produced. I am also one of the mosque administrators. Sometimes I often message the teachers about the excess of alms. For instance, in January, I gave a message to be given a lecture about what is New Year, and February to be about what Valentine is". This is known as a doable pattern where the lecture is one way or method of bringing people to their senses. When 100 people are present, but 10 are aware, it speaks of results. Once 10 people are informed, the same number are informed again, and two additional people become aware. This is repeated, most importantly in line with the way the village or state government never stops carrying out activities. Hence, when the lecture is created and then attended by 100 people but only one person is realized, it means one output. Charity is also performed by other nations such as Latinos where they give people ingrained by culture, religion, and family customs. However, this offer is not specifically for educational institutions but majorly for society in general. ${ }^{21}$

${ }^{21}$ Cristina Chavez, "Activating the Power of the Latino Community: Engaging the Latino Community Through Volunteerism and Philanthropy" (California, USA: University of San Francisco, 2020), https://cpb-usw2.wpmucdn.com/usfblogs.usfca.edu/dist/9/244/files/2020/08/chavezcristina_6183634_66676793_Cristi na-Chavez_Final-Capstone-Report.pdf. 


\section{School Foundation and Infrastructure}

According to the village leader, even though the school system is a Gampong Foundation, some recognized figures, such as the foundation's head, the supervisor, and the principal, function as the manager. With this structure, the foundation delivers all needed items to the village, both in salaries and other forms. Based on the existence of these Gampong and foundation parties, a meeting is held with schools, foundations, and village officials to provide input or suggestions. In this meeting, school leaders request their required procurement, such as an extra building unit. Furthermore, they only propose, but later the foundation and the village decide according to priority needs based on available funds. As stated, "one more room has been requested to maximize learning because the plan was to create a specific activity centre or a type that is characteristic of the school/village." Meanwhile, the school land belongs to the village, and 3000 meters were also added to the learning area, namely the class, which is still under construction. Nevertheless, the already prepared master plan later became very complex and broad.

It was further stated that until the $4^{\text {th }}$ year, students in SD IT have reached grade 4 , each of which was divided into two classes, but only grade 3 had one class. There were around 150 students, which were divided into $40 \%$ blangkrueng (native) residents and $60 \%$ non-native. Supposing the awareness was published, SD IT tends to become more expansive, and there is also a possibility for more students, but the current population is high for the village to handle. The same situation applies to the school teachers who are not civil servants or in other working categories. As stated, "they were chosen by the community to serve in the village by becoming teachers.

Nonetheless, the existing teachers were selected among the linear persons to ensure problems are not encountered later in the study program and during accreditation, such as the department of primary teacher training (or called PGSD for the institution in Ministry of Education and Culture, and PGMI for the institution in Ministry of Religious Affairs, in Indonesia)." The, tahfidz teachers were not required to pass S1. Because, during recruitment, it is always stated that applicants do not need to be requested of an education certificate for their names to be included in the prodik. Hence, the village officials tried including the available persons, and the process began with an interview. 
Meanwhile, the kindergarten teachers were required of an S1 background, but some only had the high school qualification.

\section{CONCLUSION}

The Acehnese are ready to donate their lives, let alone wealth, since the activity is often performed for religious purposes. Hence, in Aceh, this is not only Islamic sharia in terms of understanding the law of caning and more. There are other exciting sides to be exposed to, such as understanding the importance of education in Islam. Islam has become a kind of weltanschauung because this religion is the foundation for all aspects of the Acehnese lives ${ }^{22}$. Therefore, the tradition of investing is not something foreign. The problem, in general, is that the condition of the people is far from prosperous. Despite having fertile land and abundant crops, the results of natural wealth are still far from the welfare of the people. Therefore, to invest and adequate management, good awareness, and confidence, financial resources are available to enhance the activity's occurrence. It was concluded that the dimensions of funding or funding sources for developing Islamic education had not received attention. Nowadays, the focus of education studies in the province is still a lot in the curriculum ${ }^{23}$. There is a need to consider explaining the meaning of infaq and shadaqah as well as how appropriate learning is to build the character of students interested in investment. This character is important because giving infaq also needs to be internalized both to students and their parents.

\section{ACKNOWLEDGMENTS}

LPPM UIN Sunan Kalijaga and SDIT Hafizdulilmi Bangkrueng Banda Aceh. Head master SDIT Hafidzulilmi Aceh and village head Bangkrueng Banda Aceh.

\section{DECLARATION OF CONFLICTING INTERESTS}

This research has no personal or institutional interest.

${ }^{22}$ Snouck Hourgonje, The Atjehnese (Leaden: E.J. Brill, 1906); T.J. Siegel, The Rope of God (California: University of California Press, 1969); Rober W Hafner (ed), Making Modern Muslim: The Politic of Islamic Education in Southeast Asia (Honolulu: The University of Hawai Press, 2009).

${ }^{23}$ Eka Srimulyani and Sa'eda Buang, "Pendidikan Islami (Islamic Education): Reformulating A New Curriculum From Muslim Schools In Aceh Indonesia”, in Sa'eda Buang and Phyllis Ghim-Lian Chew, Muslim Education in the 21st Century: Asian Perspectives (London: Routledge, 2014). 


\section{FUNDING}

This research was funded by LPPM UIN Sunan Kalijaga in 2018.

\section{ORCID iD}

Maemonah (iD) https://orcid.org/0000-0003-2007-0877

Fitri Yuliawati iD https://orcid.org/0000-0001-6862-2082

\section{REFERENCES}

Ab Rahman, Azira Hanani, and Sofri Yahya. "The Relationship between Reputation and Infaq Collection among Islamic Private Schools and the Role of Governance Practice as Moderator," 75-76. Adya Hotel, Langkawi Island, Kedah, Malaysia, 2017. http://repo.uum.edu.my/24538/.

Abuza, Zachary. "Funding Terrorism in Southeast Asia: The Financial Network of A1 Qaeda and Jemaah Islamiya." Contemporary Southeast Asia: A Journal of International and Strategic Affairs 25, no. 2 (2003): 169-99. https://muse.jhu.edu/article/387728.

Alfian, "The Ulama In Acehnese Society: A Preliminary Observation," Southeast Asian Journal of Social Science 3, no. 1 (1975): 27-41, https://www.jstor.org/stable/24489966.

Arikunto, Suharsimi. Prosedur Penelitian: Suatu Pendekatan Praktek. Jakarta: Rineka Cipta, 1998.

Buang, Sa'eda, and Phyllis Ghim-Lian Chew. Muslim Education in the 21st Century: Asian Perspectives. London: Routledge, 2014.

Chavez, Cristina. "Activating the Power of the Latino Community: Engaging the Latino Community Through Volunteerism and Philanthropy." California, USA: University of San Francisco, 2020. https://cpb-usw2.wpmucdn.com/usfblogs.usfca.edu/dist/9/244/files/2020/08/chavezcristina_618 3634_66676793_Cristina-Chavez_Final-Capstone-Report.pdf.

Frankenberg, Elizabeth, Bondan Sikoki, Cecep Sumantri, Wayan Suriastini, and Duncan Thomas. "Education, Vulnerability, and Resilience after a Natural Disaster." Ecology and Society: A Journal of Integrative Science for Resilience and Sustainability 18, no. 2 (2013): 16. https://doi.org/10.5751/ES-05377-180216.

Hadi, Amirul. "Aceh and the Portuguese : a study of the struggle of Islam in southeast Asia, 1500-1579." McGill University. Accessed February 5, 2021. https://escholarship.mcgill.ca/concern/theses/9306t0349.

Hourgonje, Snouck. The Atjehnese. Leaden: E.J. Brill, 1906.

Ismail, Badruzzaman. Mesjid Dan Adat Meunasah Sebagai Sumber Energi Budaya Aceh. Banda Aceh: Gua Hira, 2002.

Latief, Hilman. "Health Provision for the Poor Islamic Aid and the Rise of Charitable Clinics in Indonesia." South East Asia Research 18, no. 3 (September 1, 2010): 503-53. https://doi.org/10.5367/sear.2010.0004. 
Lukens-Bull, Ronald A. "Two Sides of the Same Coin: Modernity and Tradition in Islamic Education in Indonesia." Anthropology \& Education Quarterly 32, no. 3 (2001): 350-72. https://doi.org/10.1525/aeq.2001.32.3.350.

Marzuki, Marzuki. "Sejarah Dan Perubahan Pesantren Di Aceh.” Millah: Jurnal Studi Agama 11, no. 1 (2011): 221-33. https://doi.org/10.20885/millah.vol11.iss1.art11.

Mashuri, Mashuri. "Dinamika Sistem Pendidikan Islam Di Dayah.” Jurnal Ilmiah Didaktika: Media Ilmiah Pendidikan Dan Pengajaran 13, no. 2 (February 1, 2013). https://doi.org/10.22373/jid.v13i2.477.

Nurhayati, Sri, and Dodik Siswantoro. "Factors on Zakat (Tithe) Preference as a Tax Deduction in Aceh, Indonesia." International Journal of Nusantara Islam 3, no. 1 (August 13, 2015): 1-20. https://doi.org/10.15575/ijni.v3i1.133.

Riyaldi, Muhammad Haris, and Farah Maulida Sari. "The Analysis of Welfare Determinant Factors of Recipients Zakat, Infaq and Sedekah (ZIS) Productive in Baitul Mal Aceh.” In International Conference of Zakat, 2018.

Rosa Diyana. "Filantropi Pendidikan Studi Kasus Komunitas Yogyakarta Coin A Chance." Skripsi, UIN Sunan Kalijaga Yogyakarta, 2016. https://digilib.uinsuka.ac.id/id/eprint/20989/.

Sabirin, Masriza, Muslim Zainuddin, Teuku Zulyadi, Nurul Husna, and Syazwani Drani. "The Assistance Model of the Baitul Mal in Promoting The Community of Home Industry." International Journal of Criminology and Sociology 9 (September 7, 2020): 357-64. https://doi.org/10.6000/1929-4409.2020.09.34.

Saputro, Eko Gondo, and Sahabudin Sidiq. "The Role of Zakat, Infaq and Shadaqah (ZIS) in Reducing Poverty in Aceh Province." International Journal of Islamic Economics and Finance (IJIEF) 3, no. 0 (September 2, 2020): 63-94. https://doi.org/10.18196/ijief.3234.

Siegel, T.J. The Rope of God. California: University of California Press, 1969.

Suprayogo, Imam. Quo Vadis Madrasah: Gagasan, Aksi Dan Solusi Pembengunan Madrasah. Yogyakarta: Hikayat, 2007.

Syamsidik, Rina Suryani Oktari, Agus Nugroho, Mirza Fahmi, Anawat Suppasri, Khairul Munadi, and Rajuli Amra. "Fifteen Years of the 2004 Indian Ocean Tsunami in Aceh-Indonesia: Mitigation, Preparedness and Challenges for a Long-Term Disaster Recovery Process." International Journal of Disaster Risk Reduction 54 (February 15, 2021): 102052. https://doi.org/10.1016/j.ijdrr.2021.102052.

Umar, Hussain. Metode Penelitian Untuk Skripsi, Tesis, Dan Disertasi. Jakarta: Rajawali Press, 2011.

W Hafner (ed), Rober. Making Modern Muslim: The Politic of Islamic Education in Southeast Asia. Honolulu: The University of Hawai Press, 2009. 
The Role Of Infaq...

This page is intentionally left blank

144 | Al-Bidayah, Volume 13, Number 1, June 2021 